\title{
The Vulnerable giant anteater Myrmecophaga tridactyla: new records from the Atlantic Forest highlands and an overview of its occurrence in protected areas in Brazil
}

\author{
Fernando C. Passos, Michel C.H. Mello, Emiliana Isasi-Catalá \\ Raphael C. Mello, Itiberê P. Bernardi \\ Luiz H. VARZINCZAK and CAmila S. Lima
}

\begin{abstract}
The giant anteater Myrmecophaga tridactyla is categorized as Vulnerable on the IUCN Red List, and is extinct in several locations as a result of environmental pressures. We present the first records of the giant anteater in the largest continuous expanse of the Atlantic Forest biome, in southern Brazil, highlighting its occurrence in the highlands of the Serra do Mar mountain range. During a camera-trapping survey of medium and large mammals we obtained two records of the species, one in 2013 and the other in 2014. These records from dense rainforest highlands indicate the importance of this environment for the giant anteater and highlight these areas as possible foci for future studies of the species. In addition, we present a review of the species' occurrence in protected areas in Brazil, to provide a resource for the conservation of this species and for future reevaluations.
\end{abstract}

Keywords Brazil, flagship species, giant anteater, IUCN, new record, Paraná State, Pilosa, red lists

To view supplementary material for this article, please visit https://doi.org/10.1017/So030605316000740

The giant anteater Myrmecophaga tridactyla (Mammalia,
Pilosa, Myrmecophagidae) is a large mammal with a
wide geographical distribution. It originally occurred from
northern Central America to southern South America
(Miranda et al., 2014a) but is now considered to be rare in
some regions, with low population densities (Braga, 2009).
The species' life-history traits, including diet specificity, low

Fernando C. Passos ${ }^{*}$ (Corresponding author), Raphael C. Mello, Itiberê P. Bernardi*, Luiz H. Varzinczak ${ }^{*}$ and Camila S. Lima* Departamento de Zoologia, Laboratório de Biodiversidade, Conservação e Ecologia de Animais Silvestres, Caixa Postal 19020, Universidade Federal do Paraná, Curitiba, Paraná, Brazil. E-mail tatopassos@gmail.com

Michel C. H. Mello Instituto Ambiental do Paraná, Curitiba, Paraná, Brazil

Emiliana Isasi-Catalá Emiliana Isasi-Catalá Fundación para La Defensa de la Naturaleza, Caracas, Venezuela

*Also at: Programa de Pós-Graduação em Ecologia e Conservação, Universidade Federal do Paraná, Curitiba, Paraná, Brazil

Received 9 March 2016. Revision requested 10 May 2016.

Accepted 28 June 2016. First published online 14 November 2016.

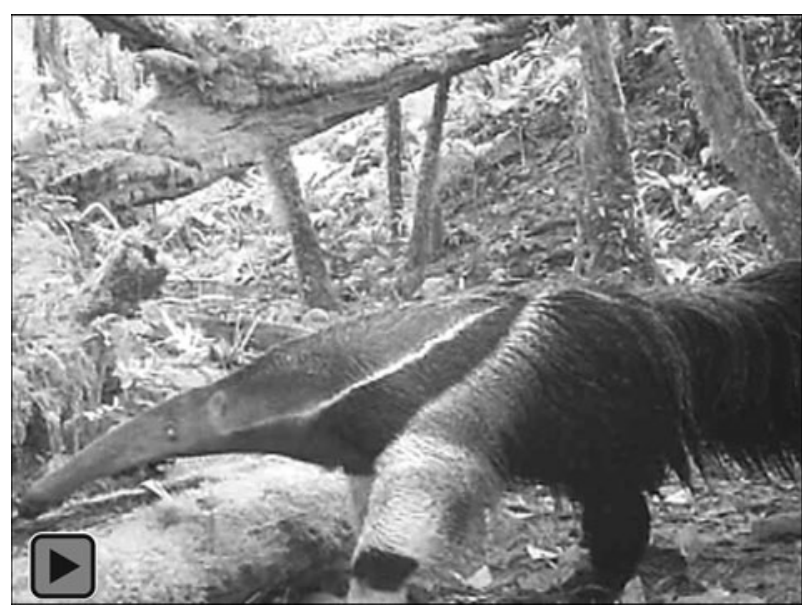

Plate 1 A giant anteater Myrmecophaga tridactyla and its habitat in the highland areas of dense rainforest (Atlantic Forest sensu stricto), in southern Brazil.

reproductive rates and large body size, together with the threats of road-kill and habitat degradation through habitat loss and fire in many areas of its range, are factors influencing its decline (Miranda et al., 2014a).

For these reasons $M$. tridactyla is categorized as Vulnerable on the IUCN Red List (Miranda et al., 2014b). Although the species was recorded in the Colombian Andes during 2013-2015 for the first time in over 100 years (Figel et al., 2016), it is considered to be extinct in Belize, Costa Rica and Guatemala, and regionally extinct in Uruguay, and little is known about its status in other areas, including parts of Brazil (Miranda et al., 2014a,b). Although it is considered to have a preference for open habitats, M. tridactyla has been recorded in all Brazilian biomes (Miranda et al., 2014a). Its occurrence in forest environments has been linked to the need for thermoregulation (Camilo-Alves \& Mourão, 2006), rest (Medri \& Mourão, 2005) and protection (Kreutz et al., 2012).

The Atlantic Forest is composed of four main vegetation types (INPE \& SOS Mata Atlântica, 2014): dense rainforest (i.e. Atlantic Forest sensu stricto), which extends from the coastal region of Brazil to the highlands of the Serra do Mar; mixed rainforest (i.e. Araucaria moist forest); and seasonal semi-deciduous and deciduous forests, both of which 


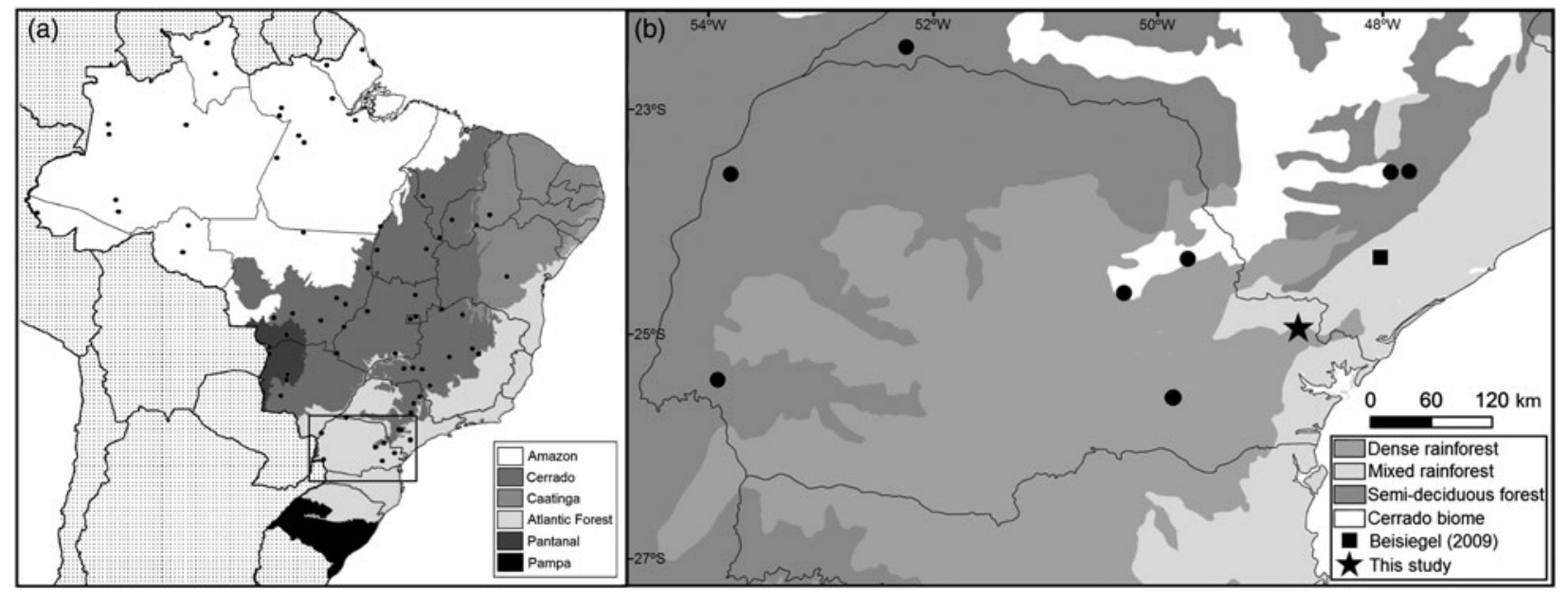

FIG. 1 (a) Occurrence records of the giant anteater Myrmecophaga tridactyla in protected areas in Brazil (Miranda et al., 2014a; Diniz \& Brito, 2015; Supplementary Table S1). (b) Occurrence records in Paraná State, including those recorded in the dense rainforest of Parque Estadual das Lauráceas in this study, and the records of Beisiegel (2009) in Parque Estadual Carlos Botelho in São Paulo State.

occur in the interior of this biome. Although the giant anteater has been recorded in dense forest, records of the species in dense Atlantic Forest are scarce. According to records for 1906-1968 M. tridactyla occurred in dense rainforest in the state of Espirito Santo, south-eastern Brazil, but the species is now extinct in this state (Moreira et al., 2008).

We report the first record of $M$. tridactyla in dense rainforest highlands in the largest continuous expanse of Atlantic Forest in southern Brazil. This is one of the first records of the species in this vegetation type within a protected area. To provide a context for these sightings we present an overview of the occurrence of the species in protected areas in Brazil.

We recorded $M$. tridactyla in the 32,000 ha Parque Estadual das Lauráceas, in Paraná State, southern Brazil. This park is in a mountainous area of the Atlantic Forest biome and includes dense rainforest (Atlantic Forest stricto sensu) and patches of mixed rainforest (Araucaria forest) at 400-1,400 $\mathrm{m}$ altitude. The climate is subtropical (Cfb Köeppen), with mean annual rainfall of $1,450 \mathrm{~mm}$ and mean annual temperature of $17.7^{\circ} \mathrm{C}$ (IAP, 2002). We surveyed medium and large mammals in dense rainforest over a 17-month period during July 2013-December 2014, using a mean of 10 camera traps (Trophy Cam, Bushnell Outdoor Products, Overland Park, USA) spaced c. $1 \mathrm{~km}$ apart and in permanent operation throughout the study period in areas of Atlantic Forest of advanced successional stage. The total survey effort was c. 4,590 camera-days. Of the 941 video recordings of medium and large mammals obtained, two were of $M$. tridactyla (Plate 1). The species was first recorded on 6 November 2013 at 16.40 , close to a watercourse at an altitude of $983 \mathrm{~m}$. The second record occurred at another camera trap station on 3 February 2014 at 16.39, at an altitude of $868 \mathrm{~m}$.

These records of the giant anteater supplement those obtained by Beisiegel (2009), who recorded it along with other medium and large-sized mammal species in the state park Parque Estadual Carlos Botelho, São Paulo State, which is an area of dense rainforest c. $110 \mathrm{~km}$ north of Parque Estadual das Lauráceas. The species has now been recorded in 72 protected areas in Brazil: 21 in the Amazon, 34 in the Cerrado, five in the Pantanal and three in the Caatinga, and nine in Atlantic Forest (Fig. 1; Supplementary Table S1). Our records are the first in dense rainforest in southern Brazil (Fig. 1; Miranda et al., 2014a).

These records in Parque Estadual das Lauráceas are from the largest remnant of the Atlantic Forest and provide new information about the species' range. This park is the largest fully protected area in Paraná State (IAP, 2002) but although the park is well preserved the surrounding region has suffered environmental pressures, including the illegal extraction of the heart of the palm Euterpe edulis, plantations of Pinus spp., and hunting. In neighbouring states M. tridactyla is categorized as Critically Endangered (IAP, 2010; $\mathrm{FZB}, 2014)$.

In the state of Rio Grande do Sul, for example, the last record is a sighting in the northern part of the state in 1999 (Oliveira \& Vilella, 2003). In the state of Santa Catarina there is disagreement between the state, which considers the species to be extinct, and researchers (Miranda et al., 2014a). Thus, the state of Paraná may now be the southern limit of the distribution of M. tridactyla in Brazil.

Historically, there has been little research on the conservation of M. tridactyla in Brazil, and such studies by state governments and researchers are hindered by a lack of knowledge about the species' biology (Diniz \& Brito, 2012). This situation is exacerbated in the Atlantic Forest, where studies of $M$. tridactyla are particularly scarce. In contrast, studies on the species' ecology, such as population density, distribution, genetic diversity, activity patterns 
and habitat use predominate and have been conducted largely in open areas of the Pantanal and Cerrado (e.g. Medri \& Mourão, 2005; Camilo-Alves \& Mourão, 2006; Collevatti et al., 2007). In the unprotected areas in which the giant anteater is known to occur it inhabits a fragmented landscape and is exposed to threats such as road traffic, domestic dogs, fires and urbanization (Cáceres et al., 2010; Miranda et al., 2014a; Miretzki \& Braga, 2014). Connectivity between protected areas, which is crucial for the species' persistence through the maintenance of genetic diversity, is poor and therefore of concern. The creation of wildlife corridors would be an invaluable tool to enhance the effectiveness of conservation strategies for M. tridactyla.

Considering the threats and pressures facing the giant anteater, the records reported here show the importance of continuous Atlantic Forest and its highland areas in maintaining the population of the species in protected areas in southern Brazil. Our compilation of records of the species' occurrence in the protected areas of Brazil is a resource for future re-evaluations of the species' distribution and conservation status.

\section{Acknowledgements}

We are grateful for the grant awarded to FCP (303757/ 2012-4) by the National Council for Technological and Scientific Development, and for the grants awarded to IPB, LHV and CSL by the Coordination for the Improvement of Higher Education Personnel.

\section{Author contributions}

FCP, MCHM and IPB conceived the research. MCHM, IPB, RCM, EIC and FCP collected the data. FCP, LHV and CSL analysed the data and wrote the manuscript.

\section{References}

Beisiegel, B.M. (2009) First camera trap record of bush dog in the state of São Paulo, Brazil. Canid News, 12, 1-5.

BragA, F. (2009) Plano de conservação para tamanduá-bandeira (Myrmecophaga tridactyla). In Planos de Conservação para as espécies de Mamíferos Ameaçados, pp. 14-3o. Instituto Ambiental do Paraná, Curitiba, Paraná.

Cáceres, N.C., Hannibal, W., Freitas, D.R., Silva, E.L., Roman, C. \& CAsella, J. (2010) Mammal occurrence and roadkill in two adjacent ecoregions (Atlantic Forest and Cerrado) in south-western Brazil. Zoologia, 27, 709-717.

Camilo-Alves, C.S.P. \& Mourão, G.M. (2006) Responses of a specialized insectivorous mammal (Myrmecophaga tridactyla) to variation in ambient temperature. Biotropica, 38, 52-56.

Collevatti, R.G., Leite, K.C.E., Miranda, G.H.B. \& Rodrigues, F. H.G. (2007) Evidence of high inbreeding in a population of the endangered giant anteater, Myrmecophaga tridactyla
(Myrmecophagidae), from Emas National Park, Brazil. Genetics and Molecular Biology, 30, 112-120.

Diniz, M.F. \& BRITO, D. (2012) The charismatic giant anteater (Myrmecophaga tridactyla): a famous John Doe? Edentata, 13, 76-83.

Diniz, M.F. \& BRito, D. (2015) Protected areas effectiveness in maintaining viable giant anteater (Myrmecophaga tridactyla) populations in an agricultural frontier. Natureza \& Conservação, 13, 145-151.

Figel, J.J., Botero-Cañola, S., Sánchez-Londoño, J.D. \& Quíntero-Ángel, A. (2016) Unexpected documentation and inter-Andean range expansion of a vulnerable large mammal (Mammalia, Pilosa, Myrmecophaga tridactyla) in Colombia. Mammalia, 8o, 449-452.

FZB (FundaÇÃo Zoobotânica) (2014) Livro Vermelho da Fauna Ameaçada de extinção do Rio Grande do Sul. 2nd edition. Http:// www.fzb.rs.gov.br [accessed 3 February 2016].

IAP (Instituto Ambiental do Paraná) (2002) Plano de Manejo do Parque Estadual das Lauráceas. IAP, Curitiba, Brazil.

iaP (Instituto Ambiental do Paraná) (2010) Mamíferos ameaçados no Paraná. IAP, Curitiba, Brazil.

INPE \& SOS Mata A AllânTiCa (2014) Atlas dos remanescentes florestais da Mata Atlântica Período 2012-2013. Http://mapas.sosma. org.br/site_media/download/atlas_2012-2013_relatorio_tecnico_ 2014.pdf [accessed 1 June 2016].

Kreutz, K., Fischer, F. \& Linsenmair, K.E. (2012) Timber plantations as favourite habitat for giant anteaters. Mammalia, 76, 137-142.

Medri, I.M. \& Mourão, G. (2005) Home range of giant anteaters (Myrmecophaga tridactyla) in the Pantanal wetland, Brazil. Journal of Zoology, 266, 365-375.

Miranda, F.R., Chiarello, A.G., Röhe, F., Braga, F.G., Mourão, G.M., Miranda, G.H.B. et al. (2014a) Avaliação do risco de extinção de Myrmecophaga tridactyla Linnaeus 1758 no Brasil. Http://www. icmbio.gov.br/portal/faunabrasileira/lista-de-especies/7127mamiferos-myrmecophaga-tridactyla-tamandua-bandeira [accessed 26 January 2016].

Miranda, F., Bertassoni, A. \& Aвв A, A.M. (2014b) Myrmecophaga tridactyla. The IUCN Red List of Threatened Species 2014: e. T14224A47441961. Http://dx.doi.org/10.2305/IUCN.UK.2014-1. RLTS.T14224A47441961.en [accessed 15 September 2016].

Miretzki, M. \& BraGA, F.G. (2014) Distribuição histórica e recente de Myrmecophaga tridactyla Linnaeus, 1758 (Pilosa,

Myrmecophagidae) no Estado do Paraná, Brasil. Edentata, 15, 16-26.

Moreira, D.O., Coutinho, B.R. \& Mendes, S.L. (2008) O status do conhecimento sobre a fauna de mamíferos do Espírito Santo baseado em registros de museus e literatura científica. Biota Neotropica, 8, 163-173.

Oliveira, E.V. \& Vilella, F.S. (2003) Xenartros. In Livro Vermelho da Fauna Ameaçada de Extinção do Estado do Rio Grande do Sul (eds A.A.B. Marques, C.S. Fontana, E. Vélez, G.A. Bencke, M. Schneider \& R.E. Reis), pp. 487-492. EDIPUCRS, Porto Alegre, Brazil.

\section{Biographical sketches}

FERnANDo C. Passos focuses on wildlife management and conservation of mammals. MICHEL C. H. MELLO is interested in conservation management. Emiliana Isasi-Catalá, Raphael C. Mello and ITIBERE P. BERNARDi work on mammal inventories and ecology. Luiz H. VARzinCzAK and CAmila S. Lima are interested in the ecological processes within mammal assemblages. 